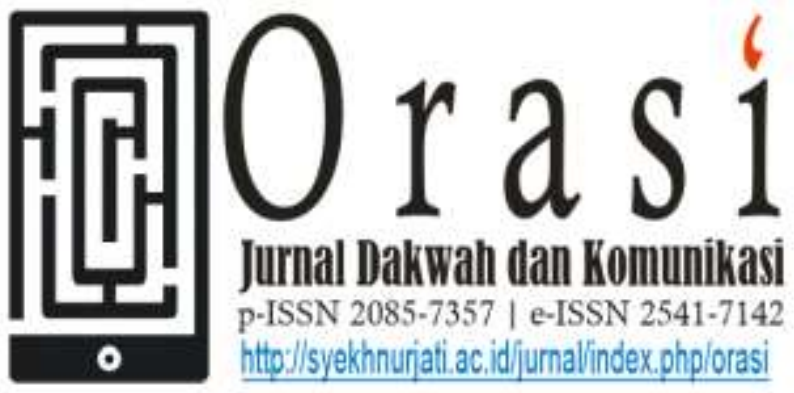

Volume 11 No. 1Juli 2020

\title{
BIAS GENDER DALAM BERITA “KASUSDRIVER TAKSI ONLINE SETUBUHI MAHASISWI ASAL MALANG DI DALAM MOBIL" (ANALISIS WACANA KRITIS SARA MILLS)
}

\section{GENDER BIAS IN THE NEWS “ONLINE TAXI DRIVER RAPES A UNIVERSITY STUDENT FROM MALANG IN A CAR” (SARA MILLS' CRITICAL DISCOURSE ANALYSIS)}

\author{
Fifi Novianty ${ }^{1, a),}$ dan Aan Mohamad Burhanudin²,b) \\ ${ }^{1}$ UIN Sunan Kalijaga Yogyakarta \\ ${ }^{2}$ IAIN Syekh Nurjati Cirebon \\ a)e-mail: noviafifi.nf@gmail.com \\ ${ }^{\text {b) }}$-mail: aan.m.burhanudin@ @yekhnurjati.ac.id
}

\begin{abstract}
Abstrak
Pemberitaan kasus Driver Online yang menyetubuhi mahasiswi asal Malang di dalam Mobil menambah kasus kekerasan terhadap wanita. Dalam berita ini terdapat bias gender pada posisi wanita atau mahasiswi asal Malang. Wanita dalam berita ini digambarkan sebagai wanita yang lemah dan tidak bisa berbuat apa-apa, dalam beritanya tidak dijelaskan identitas wanita tersebut. Peneliti akan menggunakan dua media yang ingin di teliti yaitu berita yang dimuat oleh TribunSurabaya.Com dan TribunJateng.Com. Penelitian ini dianalisis menggunakan model analisis Wacana Kritis Sara Mills, lalu menggunakan teori Feminisme dan Kesetaraan Gender. Dalam hasil penelitian ini, Media menutupi identitas dari korban dan menggambarkan korban pada posisi yang lemah atau sebagai wanita yang tidak memiliki kuasa. Media hanya fokus pada pemberitaan driver online dan mengalihkan perhatian publik pada kronologi kejadian bukan kepada nasib korban. Lalu mengalihkan perhatian publik sehingga bias gender pada berita kasus Driver Online Setubuhi Mahasiswi asal Malang sangat terlihat jelas. Dan ada relasi sosial, baik relasi antar lingkungan dengan masyarakat maupun antara laki-laki dengan perempuan.
\end{abstract}


Kata Kunci : Feminisme, Kekerasan, Wacana

\begin{abstract}
The coverage of the Online Driver case which fucked Malang students from in the Car added to cases of violence against women. In this news there is a gender bias in the position of women or female students from Malang. The woman in this news is described as a woman who is weak and cannot do anything, in her news, the woman's identity is not explained. Researchers will use two media that want to be examined, they are news published by TribunSurabaya.Com and TribunJateng.Com. This study was analyzed using the Sara Mills Critical Discourse analysis model, then using the theory of Feminism and Gender Equality. In the results of this study, the Media covered the identity of the victim and described the victim in a weak position or as a woman who has no power. The media only focuses on reporting online drivers and turning public attention to the chronology of events not to the fate of victims. Then it distracts the public's attention so that the gender bias in the news of the Case Driver Online from Malang Female Students is very clear. And there are social relations, both relationships between the environment and the community and between men and women.
\end{abstract}

Keywords: Discourse, Feminism, Violence.

\section{Pendahuluan}

Bahasa merupakan unsur utama di dalam proses realitas (Badara 2012). Proses konstruksi realitas dimulai ketika seorang konstruktor melakukan objektivikasi terhadap suatu kenyataan, yakni melakukan persepsi terhadap suatu objek. Selanjutnya, hasil dari pemaknaan melalui persepsi itu di internalisasikan ke dalam diri seorang konstruktor. Dalam tahap itulah dilakukan konseptualisasi terhadap suatu objek yang dipersepsi. Langkah terakhir adalah melakukan eksternalisasi atas hasil dari proses perenungan secara internal tadi melalui pernyataanpernyataan. Alat untuk membuat pernyataan tersebut tiada lain adalah kata-kata suatu konsep atau bahasa (Badara 2012).
Keberadaan bahasa tidak lagi hanya sebagai alat untuk menggambarkan (makna citra) mengenai suatu realitas-realitas media yang akan muncul di benak khalayak. Selanjutnya, media massa memiliki berbagaiu cara memengaruhi bahasa dan makna : mengembangkan kata-kata baru beserta makna asosiatifnya, memperluas makna dari istilahistilah yang ada, mengganti makna lama sebuah istilah dan makna baru, memantapkan konversi makna yang telah ada dalam suatu sistem bahasa.

Dalam analisis wacana bahasa dipandang memiliki fungsi tertentu. Dalam hal ini, bahasa didayagunakan untuk kepentingan tertentu. Baik itu motif ideologis dan politis. Politik berkaitan dengan disiarkannya suatu berita. Pers tidak pernah lepas dari masalah

[Orasi: Jurnal Dakwah dan Komunikasi | Volume 11, No. 1, Juli 2020 
politik, sebab kehidupan pers merupakan indikator demokrasi. Demokratis tidaknya suatu negara antara lainditentukan oleh kehidupan persnya, yaitu bebas atau tidak.

Media massa di hebohkan kembali dengan berita kekerasan pada wanita, berita yang dimuat oleh Tribun.Com pada 03 Desember 2019 yang berjudul "Driver Taksi Online Setubuhi Mahasiswi Asal Malang Di Dalam Mobil" menjadi banyak perhatian masyarakat. Ditahun 2019 ini sudah banyak media yang memuat berita tentang kekerasan pada wanita. Setiap media pasti memiliki sudut pandang tersendiri dalam menuliskan dan mengembangkan subjek dan objek yang ingin dijadikan berita. Disinilah peran analisis wacana dalam sebuah media berperan, bagaimana media tersebut mengembangkan fakta yang ada di lapangan dengan menganilisnya ke dalam praktik sosial yang berkembang di masyarakat.

\section{Landasan Teori}

\subsection{Perempuan dalam Media}

Women Discouse adalah perbincangan mengenai perempuan yang belum dan kemungkinan besar tidak akan pernah berujung. Selalu ada saja new topik yang menarik untuk diperbincangkan public dan menjadi private headline isu keseharian. Persoalan demi persoalan seolah tak kunjung habis terkupas dalam menanggapi isu keperempuan, mulai dari kekerasan, diskriminasi, pelecehan seksual, korban skandal, politik hingga emansipasi wanita. Nyatanya istitilah emansipasi ini merupakan bukti realitas penindasan terhadap perempuan, baik secara hak maupun kewajiban (Bungin 2012).

Lahirnya suatu emansipasi sebagai ekspresi nyata penuntutan terhadap kebebasan hak-hak perempuan, emansipasi sendiri bukan berarti bermakna hak yang sama dengan kaum laki-laki, namun emansipasi memiliki makna yang sangat penting yaitu untuk membentuk perikeadilan dan hal tersebut tidak harus sama. Perempuan menuntut hak yang seimbang sebagaimana pemenuhan hak terhadap kaum lelaki. Jika lelaki memiliki hak penuh berpolitik, demikian juga dengan perempuan memiliki hak juga untuk menjadi kuli atau pekerja kasar seperti lelaki. Isu apapun tentang perempuan akan selalu menjadi konsumsi publik yang renyah dan ramai dalam perdebatan.

Satu-satu nya yang menjadi alat penting dan paling berperan dalam menyebarkan isu dan sebuah perbincangan perempuan adalah media massa, bahkan terlahir asumsi yang menyatakan media massa dan perempuan bagaikan bilahan pisau yang saling melekat erat tak terpisahkan. Kedua nya terikat dengan kaitan yang saling melengkapi. Terjadi iklim saling membutuhkan, perempuan memanfaatkan jasa media massa demi untuk meningkatkan popularitasnya, sebaliknya media massa menjadikan perempuan sebagai kebutuhan yang unique dari sebuah perbincangan opini. Mulai dari sisi keberhasilan karier dan jabatannya, ketegarannya menyikapi sebuah persoalan besar. Dan banyak hal terkait persamaan dengan kaum lelaki. 
Media menegaskan bahwa wanita selayaknya adalah kaum lemah. Lihat saja beberapa kasus dalam peran wanita ditayangan televisi, maupun berita di koran hampir semuanya mengadopsi peran lemah, pembantu rumah tangga, objek kekerasan, dan lain halnya. Kondisi demikian adalah penegasan media terhadap emansipasi wanita. Persoalan yang masih terus dalam perdebatan adalah wanita menerima cap tersebut seolah itulah nilai apa adanya. Hal yang seharusnya bersebrangan dengan perjuangan kartini. Apa boleh buat, media menguasai permainan dan wanita hanya salah satu dari permainan.

Industri media, dalam perbincangannya tidak akan terlepas dari pekerja media atau profesi jurnalisme yang ada didalamnya. Kedua form tersebut, antara industri media dan profesi jurnalis senantiasa terlibat dalam dialektika penuh corak sepanjang masa. Hubungan media dan perempuan pun tak lain sebagai kaitanmutualis simbolis. Rotasi media yang memilih pada jalur kepentingan kapitalis tidak lain adalah aturan yang berlaku dalam media. Perempuan, sebagai objek kebutuhan pemberitaan tidak terlepas dari regulasi media yang bertujuan untuk sebuah keuntungan.

Tantangan terbesar bagi para jurnalis dalam menyikapi hukum pasar adalah distorsi dan peran media hanya pada standar-standar ekonomi semata yaitu keuntungan. Media kerap tak kuasa untuk menahan hasrat untung, meski harus mengorbankan idealisme dan profesionalisme.
Popularitas adalah bagian dari alasan penting kenapa perempuan bersedia menjadi olahan media, berbagai keindahan tubuh dengan publik. Bagi negara-negara liberal, perempuan memahami emansipasi sebagi kebebasan bertindak dan ekspresi, namun di Indonesia mendefinisikan emansipasi seperti diatas adalah salah. Bagaimanapun, budaya ketimuran yang mengadopsi karaketr menjaga malu, misalnya berbusana tertutup adalah bagian dari identitas ke-Indonesiaan. Untuk dapat memenuhi kondisi tersebut, perempuan tidak serta merta berdiri sendiri untuk mempertahankan batas-batas eksploitasi. Namun, pihak media seperti dijelaskan diatas memiliki andil besar dengan sentuhan moral dan etika.

Munculnya anggapan bahwa wanita selalu menjadi objek eksploitasi media, adanya kesalahan anggapan bahwa pose-pose vulgar perempuan yang ada di media massa merupakan perwujudan nilai seni, bisa jadi ini bukan sebuah kesalahan, namun terlalu dilebih lebihkan untuk mengatakan vulgar adalah seni. Jika melihat kondisi sekarang, vulgar yang disajikan oleh berbagai media massa jauh dari kesan seni, yang benar adalah pornografi bukan hasil karya seni. Pornografi yang share ke publik merupakan perbuatan pelecehan terhadap martabat perempuan karena dalam pornografi selera murahan disebarluaskan tanpa harga. Berawal dari sinilah skandal dimulai, pornografi kebanyakan membangkitkab selera rendah yang menjadikan perempuan sebagai objek, padahal 
sensualitas perempuan penuh dengan sensualitas kasih sayang bukan sensualitas yang rendahan.

\subsection{Eksploitasi Perempuan dalam Media Massa}

Media massa sering menggunakan perempuan sebagai objek berita agar menarik perhatian pembaca. Eksploitasi perempuan pada media massa sendiri memiliki makna menggunakan penggambaran perempuan dalam publikasi media (seperti televisi, koran cetak,film, media daring dan iklan) untuk meningkatkan perhatian pada media atau produk tersebut namun berdampak merusak dan tidak menghormati hak perempuan yang bersangkutan atau perempuan secara keseluruhan. Media di konsumsi oleh jutaan orang di seluruh dunia dan informasi yang disebarkan dapat menghasilkan strereotip dan norma sosial yang berusaha membentuk standarisasi terhadap perempuan. Bentuk eksploitasi media terhadap perempuan yang kerap di kritik oleh penggiat feminisme adalah obyektifitas seksual.

\subsection{Stereotipe Perempuan dalam Media}

Media di Indonesia telah memunculkan stereotipe terhadap perempuan yang melekat dalam berbagai tayangan; dari sinetron, infotainment, telewicara, hingga berita. Gambaran tentang perempuan pemarah, pencemburu, pendendam ada dalam tayangan sinetron. Tayangan infotainment memprogandakan pasangan sebagai hal yang paling penting dalam kehidupan perempuan. Jika seorang artis perempuan tidak berpasangan, maka ia akan terus dikejar-kejar pertanyaan pekerja infotainment. Status lajang menjadi status buruk bagi perempuan yang dilekatkan oleh infotainment di televisi kita. Stereotipe lainnya yang muncul adalah status cantik yang melekat dalam industri media televisi. Siapa saja yang tampil menjadi selebritas di televisi harus selalu cantik. Jika tak cantik, maka seorang perempuan akan mendapatkan ejekan: tak seksi, kurang putih, mukanya kurang menjual, kalah pamor dari perempuan cantik lainnya (Luviana 2015).

Stereotip terhadap perempuan inilah yang bisa menimbulkan eksploitasi media terhadap perempuan. Stereotip terhadap perempuan seperti lebih mudah dijelaskan dengan bertitik tolak pada wacana yang menempatkan perempuan pada posisi yang negatif dan tak berdaya. Masyarakat di Indonesia masih memegang stereotip bahwa laki-laki berada di wilayah kiri (aktif, beradab, rasional, cerdas) sedangkan perempuan diwilayah kanan (pasif, dekat dengan alam, emosional, kurang cerdas) inilah mengapa media dengan mudah mengeksploitasi perempuan (Astuti 2016).

Selama stereotip terhadap perempuan seperti ini masih terus dipercaya oleh masyarakat, maka ketidakadilan atau deskriminasi terhadap peremouan terus saja ditampilkan oleh media walaupun sudah ada faham feminisme. Kementrian Pemberdayaan Perempuan dan Perlindungan Anak Republik Indonesia menyatakan bahwa semua bentuk ketidakadilan gender diatas berawal pada 
sumber kekeliruan yang sama, yaitu stereotipe gender laki-laki dan perempuan (Puspitasari 2013)

\subsection{Wacana Feminisme}

Menurut Stef Slembrouck secara rinci mengkategorisasikan Wacana menjadi 8 pendekatan yang digunakan dalam membangun teori atau metode analisis wacana yang berkembang dalam kurun waktu sepuluh tahun terakhir ini. Pendekatanpendekatan tersebut di antaranya adalah pendekatanfilosifis, linguistik, linguistik antropologi, cultural studies, postrukturalis, teori sosial, sosiologi. ika masing-masing pendekatan melahirkan lebih dari dua teori atau metode analisis, maka dapat dibayangkan betapa kompleksnya pengertian wacana dan analisis wacana (Purbani 2009).

Ranah linguistik memahami Wacana dengan cara pandang yang berbeda. Wacana dipahami sebagai unit kebahasanan yang lebih besar dari pada kata atau satu kalimat, yang dapat melihat satu atau lebih orang. Jadi sebuah pidato, dialog, polemik, perdebatan, percakapan, dan perbincangan dapat dikategorikan sebagai sebuah wacana. Menurut crystal and Cook mendefinisikan wacana sebagai unit bahasa lebih besar dari kalimat, sering berupa satuan yang runtut/koheren dan memiliki tujuan atau konteks tertentu (Purbani 2009).

Sedangkan feminisme juga erat hubungannya dengan perbedaan antara laki-laki perempuan juga terkait budaya. Perbedaan ini biasanya dikaitkan dengan bagaimana konstruksi budaya tentang oeran, fungsi dan sambungan laki-laki atau perempuan di dalam kehidupan sosial, politik, dan budaya.biasanya hal inilah yang menjadi alasan adanya perbedaan gender yang kurang simpatik (Muqoyyidin 2013).

Melihat persoalan tersebut, nampaknya wacana feminisme adalah salah satu topik kajian yang menarik bagi akademisi dan peneliti. Dilihat dari konsep "Feminisme" yang marak di Barat pada abad ke-19 dan 20 menjadi model bagi pembebasan perempuan di banyak Negara berpenduduk muslim. Semua bermula pada intelektual Mesir yang belajar ke Eropa, wacana feminisme yang marak di Eropa "diadopsi” oleh mereka setelah pulang dari Eropa untuk kemudian dikembangkan dan kini di kenal juga dengan istilah "Tafsir al-Mar'ah" atau “pembebasan perempuan” (Suryorini 2012).

Penelitian terdahulu tentang Wacana Feminisme juga, pernah dibuat oleh Suyanto yang berjudul "Sosok Perempuan dalam Pandangan Bung Karno pada Memoar Sarinah: Sebuah Analisis Wacana Kritis Feminis." Jurnal ini terbit di Jurnal Undip pada tahun 2019. Penelitian ini menjelaskan tentang Perempuan di Mata Soekarno. Bagian ini merupakan pembahasan hasil dari penelusuran yang dilakukan untuk mengurai pandangan Soekarno tentang perempuan. Pandangan tersebut diselidiki melalui identitas social Soekarno selaku penulis buku Sarinah. Gambaran identitas social inilah yang bisa dijadikan sebagai salah satu penyebab paling esensial yang membentuk 
praktik seksisme dalam buku Sarinah (Suyanto 2019).

Jadi dalam penelitian ini sosok perempuan 'Sarinah' memiliki tiga identitas sosial yang menyebabkan seksisme pada perempuan dalam buku Sarinah, pertama, Soekarno hanya fokus pada politisasi gerakan perempuan untuk mewujudkan gairah patriotismenya pada negara; kedua, Soekarno masih ingin mempertahankan budaya patriarki meskipun dengan berlandaskan rasa keadilan kepada sesama; ketiga, Soekarno memiliki rasa kekaguman yang besar pada keindahan dan kecantikan perempuan sehingga hal ini memengaruhi cara pandangnya terhadap perempuan (Suyanto 2019).

\section{Metode Penelitian}

Metode penelitian ini adalah metode kualitatif deskriptif. Dianalisis menggunakan model analisis Wacana Kritis Sara MillS. Adapun teori yang digunakan dalam penelitian ini adalah teori Feminisme dan Kesetaraan Gender.Penelitian ini melakukan analisis kebahasaan pada teks berita yang melibatkan konteks dan hal-hal lain di luar kebahasaan pada teks. Peneliti menggunakan berita dari dua media online yakni TribunSurabaya.Com dan TribunJateng.Com. Kedua media online ini sama-sama menulis berita tentang DRIVER TAKSI ONLINE SETUBUHI MAHASISWI ASAL MALANG DI DALAM MOBIL. Dengan menggunakan teori Feminisme, peneliti akan meneliti keberpihakan kedua media dalam membuat berita terhadap perempuan. Dan peneliti akan menguraikan teks-teks yang menyudutkan pihak perempuan dilihat dari teori Feminisme.

\section{Pembahasan}

Dalam berita yang di muat Tribun.Com mengungkapkan bahwa Driver taksi online yang melakukan aksi asusila tersebut adalah Bambang Eko Setiawan, Warga Perum Regency Sidoarjo. Akibat perbuatannya tersebut, pelaku harus menanggung hukuman berupa kurungan penjara selama 7 tahun. Berikut 5 fakta kasus Bambang Eko Setiawan driver taksi online setubuhi mahasiswi asal Malang (Arsyam 2019).

1) Kronologi Kejadian: peristiwa tak senonoh dialami korban, $\mathrm{RN}$ saat ia hendak pulang ke tempat tinggalnya di apartemen nya. Kroban memesan taksi melalui aplikasi online yang saat itu di kendarai Bambang Eko Setiawan. Pelaku melewati kawasan Midle East Ring Road atau MERR Surabaya dan memberhentikan mobil disalah satu halaman ruko. Disitulah pelaku pelampiaskan nafsu bejatnya kepada korban.

2) Langsung di bekuk beberapa jam kemudian: setelah melakukan aksi asusila tersebut, pelaku lantas pulang kerumahnya di Sidoarjo. Pihak kepolisian yang menerima laporan korban, langsung melakukan pelacakan pelaku melalui unit Jatanras Polrestabes Suarabaya.

3) Bambang Eko Setiawan Terima Getahnya: setelah di perkosa, terdakwah atau korban diturunkan di Jalan Rajwali. Saat melakukan sidang di Pengadilan Negeri 
Surabaya, majelis hakim menuntut hukuman 7 tahun penjara.

4) Korban Rugi Moril dan Materil: Majelis Hakim dalam Putusannya menyatakan perbuatan terdakwa Bambang Eko Setiawan sudah meresahkan masyarakat. Khususnya merugikan saksi RN secara moril dan materil sebagaimana diatur dan diancam dalam dakwaan JPU.

5) Kejadian Serupa di Bogor, Penumpang Taksi Online dirampas dan Dirudapaksa: kasus terpisah, F (37), sopir taksi online yang merudapaksa dan merampok korbannya, saling kenal dan sering mengantar korban. Sebelum kejadian itu, korban memasang status di aplikasi pesan ingin memakan sesuatu. Setalah itu, pelaku langsung mengajak korban ke kawasan Bogir, Jawa Barat pada Jumat (1/6/18). Dan setuju makan di Bogor, kemudian lanjut menonton. Lalu, setalah menonton korban diajak kekawasan Puncak Bogor oleh pelaku. ditengah perjalanan, pelaku meminta bersetubuh dengan korban, tapi korban menolak lalu dirudapaksa. Pelaku sempat pergi ke minimarket untuk membeli lakban. Setelah itu, mulut korban dilakban oleh pelaku didalam mobil. "Di tol Cibubur, mobil dihentikan, HP dan uang diambil. Dan korbanpun dirudapaksa”. Setelah itu, korban diturunkan di Pasar Rebo, Jakarta Timur, sedangkan pelaku melarikan diri. Polisi berhasil menangkap $\mathrm{F}$ dan menembak kakinya pada Senin (4/6/18).

\subsection{Analisis Wacana Berita TribunsSurabaya.Com \\ 4.1.1 Analisis Wacana pada Judul Driver Taksi Online Setubuhi Mahasiswi Asal Malang di dalam Mobil}

Strategi wacana yang digunakan oleh TribunSurabaya.Com pada Lead wacana beritanya ialah strategi wacana asimilasi, yaitu suatu strategi wacana yang dalam pemberitaan menyebut sebuah komunitas atau kelompok social seorang aktor. Kaitannya dengan tersangka yang ada dalam berita adalah ia ditampilkan oleh media mengacu pada sebuah komunitas Taxi Online. Memang benar tersangka Bambang Eko Setiawan merupakan seorang supir Taxi Online, namun dengan dibuatnya judul berita seperti yang dimuat oleh Tribun.Com kalimat seperti itu terkesan bahwa yang ditangkap khalayak adalah semua supir Taxi Online berkecenderungan untuk melakukan tindakan asusila terhadap penumpang perempuannya di dalam mobil ketika sedang mendapatkan orderan penumpang wanita cantik atau wanita yang membuat hasrat seksualnya meningkat.

Adapun Bambang Eko Setiawan sebagai pelaku kekerasan seksual terhadap $\mathrm{RN}$ seorang mahasiswi Malang yang pada saat itu menjadi penumpang Taxi Online yang di kemudikan oleh Bambang. Tribun.Com dalam membuat judul berita ini adalah ingin menonjolkan kepada pelaku yang bekerja sebagai supir Taxi Online. yang menjadi perhatian pembaca adalah dari kata yang mengacu pada suatu komunitas atau pekerjaan yaitu "Taxi Online" sehingga wacana 
yang dibangun oleh Tribun.Com adalah kebanyakan orang yang berlatarbelakang sebagai supir Taxi Online mudah melakukan tindakan kekerasan seksual terhadap penumpang perempuannya. Terutama jika penumpang perempuannya memiliki paras cantic dan kaya, maka akan berpotensi munculnya tindakan kekerasan seksual.

Dalam judul berita yang dimuat oleh TribunSurabaya.Com ini menimbulkan persepsi di tengah masyarakat bahwa seorang pria yang menjadi driver online memiliki kemungkinan besar untuk melakukan hal yang tidak diinginkan kepada penumpang wanita yakni seperti perlakuan pelecehan seksual dan tindakan pemerkosaan. Padahal yang melakukan hal tersebut hanya beberapa oknum saja atau tidak semua driver online melakukan hal yang keji tersebut, namun dengan membuat judul yang seperti di atas menimbulkan persepsi negatif di kalangan driver online taksi di tengah masyarakat.

\subsubsection{AnalisisWacanapada Isi WacanaBerita}

Secara umum, strategi wacana yang digunakan pada wacana berita 1 Kompas ialah strategi wacana nominasi, yaitu suatu strategi wacara yang menampilkan aktor dengan apa adanya. RN sebagai korban pemerkosan didalam mobil oleh supir Taxi Online ditampilkan secara apa adanya. Dalam wacara isi berita ini lebih menonjolkan bagaimana kronologi kejadian bagaimana korban $\mathrm{RN}$ di setubuhi oleh supir Taxi Online tersebut. Tribun.Com selalu menonjolkan informasi lebih mendalam tentang pelaku (Bambang), dan membiaskan identitas korban (RN).

Hal ini terlihat dari banyak muncul nama pelaku dalam setiap paragraf berita, dan identitas pelaku yang dijelaskan lengkap yang disajikan oleh wartawan dalam berita. Beberapa kutipan yang berkaitan dengan hal tersebut sebagai berikut:

Kasus rudal paksa kembali terjadi yang melibatkan driver taksi online di Surabaya dengan korban mahasiswi asal Malang, Jawa Timur. Driver Taxi Online yang melakukan aksi asusila tersebut adalah Bambang Eko Setiawan, warga Perum Graha Regency Sidoarjo".

Dari kutipan berita tersebut terlihat bahwa TribunSurabaya.com ingin memberitahu identitas pelaku dengan menyubutkan nama lengkap pelaku, pekerjaan dan alamat lengkap yang ditinggali oleh pelaku. sedangkan, untuk korban RN sendiri, media memposisikan perempuan sebagai sosok yang lemah dan tidak berdaya atas hasrat sexsualitas dari supir Taxi Online tersebut. dan identitas korban tidak diungkap jelas oleh TribunSurabaya.Com, hanya memberi tahu bahwa korban adalah mahasiswi asal Malang, Jawa Timur.

TribunSurabaya.Com memberi wacana dalam beritanya bahwa korban atau perempuan yang menjadi objek tidak memiliki kekuatan untuk melawan dan dalam posisi yang lemah. Berikut adalah kutipan yang terkait dengan hal tersebut:

"Peristiwa tak senonoh di alami oleh korban, RN saat ia hendak pulang ke tempat tinggalnya di apartemen yang 
ada di kawasan JL. Kalisari, Surabaya. Korban memesan taksi online melalui aplikasi di smartphone nya yang saat itu dikendarai oleh Bambang Eko Setiawan. Pelaku melewati kawasan Midle East Ring Road atau MERR Surabaya dan menghentikan mobil di salah satu halaman ruko. Disitulah pelaku melampiaskan nafsu bejatnya kepada korban. Setelah itu, pelaku membawa korban ke Jalan Perak Barat dan menurunkannya di sana".

Terlihat dari berita yang disampaikan wartawan, menyiratkan bahwa seorang korban perempuan tidak memiliki kekuatan untuk melawan dan pasrah terhadap keadaan yang sulit. Perempuan disini digambarkan lemah karena setiap ada pemberitaan pemerkosaan terhadap perempuan berita selalu memberi wacana korban atau perempuan tersebut diturunkan ditengah jalan setelah di setubuhi dan di ambil harta benda nya.

Dalam kajian feminisme dalam media, terlampau banyak perempuan yang kalah dalam kompetisi dalam media. Dilema antara karir dan harga diri merupakan hal yag melanda setiap perempuan yang selalu berada dalam lingkungan mayoritas laki-laki. Misalnya ketidakberanian mengungkapkan kepada yang berwajib karena dianggap tabu bagi masyarakat kebanyakan yang memiliki norma yang begitu mengagungkan nilai-nilai perempuan.

Penilaian cacat dari masyarakat terhadap perempuan adalah lebih dari apapun bentuk hukuman pengadilan. Ini juga yang menyebabkan betapa sedikitnya kasus pelecehan seksual terungkap, karena sistem norma masyarakat kita lebih dahulu meredamnya.

Selain dari sisi ekonomis, pelecehan seksual terjadi akibat sebuah persaingan. Melihat dari sisi biologis dan sosiologisnya. Setiap manusia memiliki potensi yang masingmasing berbeda. Termasuk kelompok besar gender mempunyai perbedaan potensi yang mendasar. Mulai dari fisik hingga non fisik lakilaki lebih maskulin dan perempuan cenderung feminim. Laki-laki lebih menyukai berpetualang dan perempuan selalu merasa aman dirumahnya. Allah SWT, memang menciptakan makhluk-Nya berpasang-pasangan. Bagi laki-laki perempuan adalah perhiasan dan untuk kesenangan. Hingga kini pernyataan. Perempuan tetaplah akan menjadi perhiasan laki-laki.

Dalam media perempuan selalu menjadi objek seksualitas bagi laki-laki. Hingga begitu banyak berita yang memuat kasus pemerkosaan pada perempuan, eksploitasi perempuan hingga jual beli perempuan. Posisi perempuan dalam kasus yang dimuat oleh TribunSurabaya.Com perempuan dianggap lemah dan tidak bisa memberontak karena dalam masyarakat telah tertanam norma yang harus menjaga nilai-nilai perempuan, perempuan dianggap lemah dan selalu mengalah kepada laki-laki. Dan laki-laki dianggap selalu berkuasa dan bisa melakukan segalanya.

Hal ini disadari oleh semua perempuan. Perkembangan budaya yang juga mengubah penampilannya, misalnya dengan seperangkat pakaian dan aksesorisnya yang seronok, justru 
dapat memancing potensi biologis laki-laki. Sehingga barang tentu bagi laki-laki akan sulit menghargai perempuan yang bertingkah laku dan perpenampilan "berani" semacam ini.

Pelecehan seksual juga bisa muncul akibat dari relasi gender yag berlebihan, dimana daerah perlindungan atau batas-batas pergaulan yang menjadi sulit untuk di taati dalam keseharian. Sistem memang telah mengkondisikan etika bergaul sedemikian rupa sehingga melazimkan apa-apa yang menurut agama tidak lazim.

Akibat dari isu perempuan yang selalu menjadi objek media adalah jika masalah kejahatan seksual ini ditilik dengan cara pandang yang sempit, maka hak-hak perempuan yang ada didalamnya akan terabaikan. Ini berarti bahwa penderitaan yang dialami kaum perempuan tetap tidak terjangkau oleh hukum dan tidak terpecahkan secara sosial.

Kekerasan terhadap perempuan merupakan wujud ketimpangan historis dari hubungan-hubungan kekuasaan antara kaum laki-laki dan perempuan yang telah mengakibatkan dominasi dan diskriminasi terhadap kaum perempuan oleh kaum laki-laki dan hambatan dalam kemajuan terhadap mereka (kaum perempuan).

Jika ditinjau secara etimologis, istilah "kesusilaan" dalam masyarakat ternyata mendapatkan menyempitan arti. Pada umunya kata "kesusilaan" selalu dihubungkan dengan hal-hal yang berbau seks atau perkelaminan saja. Seperti hal nya "wanita tuna susila", maka asosiasi kita pastilah pada perbuatan perbuatan yang berhubungan dengan pelanggaran dibidang seksual, seperti perzinahan, pemerkosaan, pelacuran, homoseksualitas, ataupun perbuatanperbuatan yang lainnya yang sifatnya : cabul, abortus, dan lain-lain.

Posisi perempuan yang dianggap lemah dalam berita ini juga, memiliki latar belakang sejarah dalam masyarakat. Larangan perkosaan didalam tradisional tidak lebih hanya untuk melindungi atau menjaga agar kaum laki-laki selalu mendapatkan seorang istri yang masih suci. Perbuatan perkosaan merupakan suatu tindak kejahatan yang amat berat apabila dilakukan terhadap mereka yang sudah menikah.

Tidak jauh beda dengan Pasal 285 KUHP tersebut diatas, yang menempatkan perempuan pada posisi yang tidak mempunyai hal apapun dalam hubungan seksual dengan suaminya (hak untuk menolak atau berkata tidak). begitu juga yang dijelaskan dalam berita ini, korban RN tidak bisa menolak perlakukan bejad dari supir Taxi Online tersebut saat menyetubuhi nya dan setelah di setubuhi korban RN lalu diturunkan di tengah jalan begitu saja. Terlihat bahwa image perempuan disini adalah tidak berdaya dan tidak memiliki kuasa yang kuat.

Masalah perkosaan yang dialami perempuan merupakan contoh kerendahan posisi perempuan terhadap kepentingan seksualitas laki-laki. Citra seksual perempuan yang telah menempati dirinya sebagai onjek seksual lakilaki ternyata berimplikasi jauh. Dalam 
kehidupan sehari-hari, kaum perempuan harus senantiasa berhdapan dengan kekerasan, pemaksaan, dan penyiksaan fisik dan psikis. Oleh karena itulah, media massa selalu memuat isu-isu tentang kekerasan wanita dan menjadikan wanita sebagai objek seksualitas dan pemuas serta kekuasaan laki-laki.

\subsection{Analisis Wacana Berita TribunJateng.Com \\ 4.2.1 Analisis Wacana pada Judul Bambang Driver Taksi Online Perkosa Mahasiswi di dalam Mobilnya, Korban Lalu di Turunkan di Jalan}

Strategi wacana yang digunakan oleh TribunJateng.Com pada lead wacana beritanya ialah strategi wacana nominasi, yaitu suatu strategi wacana yang dalam pemberitaannya menampilkan aktor pelaku dan korban apa adanya sesuai dengan fakta. Pada judul berita wartawan menggunakan nama asli pelaku sebagai judul dan menyembunyikan identitas korban dengan hanya menyebut korban sebagai Mahasiswi dan tidak dijelaskan asal Universitanya. Dari judul di atas yang menjadi objek berita adalah Bambang Driver Taxi Online yang memperkosa Mahasiswi di dalam mobil, sedangkan mahasiswi di sini hanya sebagai subjek yang identitasnya di sembunyikan oleh wartawan. Hal tersebut mengindikasikan keberpihakan redaksi TribunJateng.Com terhadap korban RN yang menjadi korban pemerkosaan Driver Taxi Online di Surabaya.

\subsubsection{Analisis Wacana pada Isi Berita TribunJateng.Com}

Strategi wacana yang digunakan pada isi berita TribunJateng.Com adalah strategi wacana nominasi, yang menampilkan seluruh kejadian dengan apa adanya berdasarkan kronologis kejadian. Dalam isi berita paragraft pertama wartawan mengungkap identitas pelaku pemerkosaan terhadap mahasiswi, dengan menyebutkan nama jelas pelaku, pekerjaan dan temoat kejadian pelaku memperkosa korban. Berikut adalah kutipan berita yang menunjukan keberpihakan media terhadap korban dengan lebih menonjolkan identitas pelaku dalam berita yang disajikan.

"Bambang Eko Setiawan, driver taksi online di Kota Surabaya setubuhi mahasiswi di dalam mobilnya di Midle East Ring Road atau MERR Surabaya. Warga Perum Graha Regency Sidoarjo tersebut melakukan kejahatannya pada 4 Desember 2019 dan kini divonis majelis hakim kurungan penjara 7 tahun" (Permadi 2019).

Dalam berita disini juga TribunJateng.Com juga membiaskan identitas korban namun ingin menunjukan kelemahan dari korban atau perempuan dari kronologi yang di ceritakan dalam berita. Dalam berita korban di gambarkan sebagai subjek yang lemah dan tidak memiliki kekuasaan apapun untuk melawan, Dan ada suatu anggapan dalam masyarakat mengapa perempuan selalu dianggap lemah dan selalu kalah oleh laki-laki. Perempuan selalu menjadi objek seksualitas oleh laki-laki, sehingga dalam media massa pun perempuan dijadikan objek untuk mendongkrak popularitas 
media dengan cara menunjukan kelemahan yang dimiliki oleh wanita.

Dalam media perempuan selalu digambarkan sebagai sosok yang lemah, dan menjadi kepuasan seksualitas bagi pria. Karena pada kenyataannya dalam masyarakat memiliki anggapan bahwa perempuan cantik dan memiliki penampilan yang mudah mengundang hasrat laki-laki bisa menjadi objek seksualitas bagi para laki-laki. Oleh karena itu media selalu mengangkat berita-berita yang menjadikan wanita sebagai objek kepuasan seksualitas lakilaki. Mulai dari kasus pemerkosaan terhadap mahasiswi, pelecehan seksualitas di angkutan umum, eksploitasi perempuan dan lain sebagainya. Anggapan yang berkembang dalam masyarakat mengenai perempuan, telah menjadi asumsi media massa yang menganggap memang betul wanita hanya untuk dijadikan objek kepuasan seksualitas bagi laki-laki, oleh karena itu media menjadikan isu perempuan untuk mendongkrak popularitas nya.

Dalam berita ini juga sosok perempuan yang menjadi korban kejahatan seksual di gambarkan sebagai posisi yang lemah. Dalam nilai masyarakat yang ada pun wanita dianggap sebagai orang yang selalu taat kepada suami atau perempuan tidak bisa melampaui kekutan lakilaki, dari situlah perempuan selalu dianggap lemah dan di dunia media massa pun ketika perempuan dijadikan subjek atau objek berita pasti digambarkan sebagai posisi yang lemah atau tertindas. Berikut kutipan berita yang menunjukan posisi lemah seorang perempuan : "kala itu korban dipaksa melayani nafsu pelaku di dalam mobil di halaman ruko di daerah MERR Surabaya. Setelah puas melampiaskan nafsunya. Eko menurunkan Korban RN di Jalan Perak Barat".

Dengan cara pandang media yang seperti ini, maka persoalan kejahatan seksual dapat dilihat sebagai akibat dari relasi sosial, baik relasi antar lingungan dengan masyarakat maupun antara laki-laki dengan perempuan. Dengan cara pandang seperti ini pula, kekaburan yang terjadi dalam praktik selama ini yang cenderung melihat kejahatan seksual lebih sebagi bentuk "keinginan seksual" akan berubah menjadi cara pandang yang melihat kejahatan seksual sebagai bentuk "dominasi seksual”. Dan dari perspektif seperti inilah, hukum positif yang mengatur tentang kejahatan seksual dapat dilihat.

Dari kejadian tersebut tentunya perempuan akan memikul akibat dari itu, apalagi sampai ia mengandung diluar pernikahan. Jelas hal ini menunjukan bahwa betapa rendahnya penghargaan laki-laki terhadap perempuan, dengan memperlakukan perempuan hanya sebagai objek pemuas kebutuhan biologis belaka.

Dari dua kasus diatas, kita berkesimpulan bahwa kaum perempuan ternyata lebih merupakan kelompok yang paling dirugikan dalam relasi ini. artinya, kemungkinan besar bahwa pria merupakan kelompok pemanfaat atas kelompok perempuan apabila kita kaji persoalan-persoalan lain. 
Bentuk kekerasan terhadap perempuan yang juga dapat dikategorikan sebagai kejahatan sexsual atau gender based violence adalah kekerasan dalam keluarga atau yang dikenal dengan istilah domestic violence.

Seperti juga pelecehan seksual, dalam hukum positif tidak kita jumpai ketentuan tentag kekerasan dalam keluarga ini. namun pada realitanya demikian, dalam keseharian sering kita jumpai, sering kita dengar, dan sering pula kita baca bahwa kejahatan ini sering terjadi, apakah itu menyangkut wanita, istri, anak, pembantu rumah tangga baik yang bekerja dalam negeri maupun luar negeri yang menjadi korban kekerasan sexsualitas laki-laki dan dijadikan objek pemberitaan oleh media massa. Dari pengalaman tersebut, maka perbuatan itu menampakan ciri-ciri antara lain: dilakukan di dalam rumah, di dalam mobil, dibalik pintu tertutup, dengan kekerasan atau penyiksaan fisik atau psikis dilakukan oleh orang yang mempunyai hubungan dekat dengan korban.

Seperti yang diungkap oleh Huzaemah T.Y, pada zaman sebelum Islam, kaum wanita selalu berada di bawah kezaliman kaum pria, diperjualbelikan laksana binatang dan barang, tidak diperbolehkan hak-hak menurut undangundang dan tidak dapat kedudukan dalam masyarakat sebagai mana yang sewajarnya diberikan kepada mereka dan seharusnya diakui oleh masyarakat. Namun, setelah Islam hak ikhwal kaum wanita menjadi baik dan menggembirakan. Islam mengangkat martabat kaum wanita dan memberikan hak-hak yang telah hancur berantakan diinjak injak oleh kaum pria dan telah hancur oleh tradisi tradisi, fanatisme dan kebangsaan.

Seperti yang dijelaskan dalam buku yang berjudul Membincangkan Feminisme (Anshori, Kosasih, dan Sarimaya 1997). Di era modernsasi dan globalisasi, posisi perempuan bukan saja tersubordinasi, tertapi juga makin tertidas dan rentan terhadap proses eksploitasi, serta kekerasan, baik dalam lingkup publik maupun pribadi. Memang, sejarah menunjukan bahwa gerakan perempuan dengan berbagai bentuk dan variasinya tidak pernah berdiri sendiri. Dia adalah bagian dari konteks masyarakat, yang keberhasilannya bergantung pada kekuatan kekuatan yang ada di masyarakat, dan dapat berimbas tidak hanya pada wanita itu sendiri, melainkan juga pada masyarakat secara keseluruhan.

\subsection{Tinjauan Hukum Atas Masalah Kekerasan Terhadap Perempuan}

Dalam dasar pertimbangan deklarasi tersebt, antara lain dikatakan bahwa kekerasan terhadap perempuan adalah perwujudan ketimpangan historis dari hubungan-hubungan kekuasaan antara kaum laki-laki dan perempuanyang telah mengakibatkan dominasi dan diskriminasi terhadap kaum perempuan oleh kaum laki-laki dan hambatan terhadap kemajuan terhadap kaum perempuan.

Deklarasi ini juga melihat bentukbentuk kekerasan terhadap perempuan (pasar 2) yang harus di pahami. 
a. Kekerasan secara fisik, seksual, dan psikologis yang terjadi dalam keluarga, termasuk pemukulan, penyalahgunaan seksual atas perempuan anak-anak dalam rumah tangga, kekerasan yang berhubungan dengan mas kawin, pemerkosaan dalam perkawinan, perusakan alat kelamin perempuan, dan praktik-praktik kekejaman tradisional lain terhadap perempuan, kekerasan diluar hubungan suami istri, dan kekerasan yang berhubungan dengan eksploitasi.

b. Kekerasan secara fisik, seksual, dan psikologis yang terjadi dalam masyarakat luas, termasuk pemerkosaan, penyalahgunaan seksual, pelecehan, dan ancaman seksual ditempat kerja, dalam lembaga-lembaga pendidikan, dan sebagainya, perdagangan perempuan dan pelacuran paksa.

c. Kekerasan secara fisik, seksual, dan psikologis yang dilakukan atau dibenarkan oleh negara di mana pun terjadi.

\section{Daftar Pustaka}

Anshori, Dadang S., Engkos Kosasih, dan Farida Sarimaya. $1997 . \quad$ Membincangkan Feminisme: Refleksi Muslimah Atas Peran Sosial Kaum Wanita. Bandung: Pustaka Hidayah.

Arsyam, Ilham. 2019. "5 Fakta Kasus Bambang Eko Setiawan Driver Taksi Online Setubuhi Mahasiswi Asal Malang Di Mobil." TribunTimur.Com, Desember 6, 2019. https://makassar.tribunnews.com/2019/12/ 06/5-fakta-kasus-bambang-eko-setiawandriver-taksi-online-setubuhi-mahasiswiasal-malang-di-mobil.

Astuti, Yanti Dwi. 2016. "Media dan Gender (Studi Deskriptif Representasi Strereotipe Perempuan dalam Iklan di Televisi Swasta." Profetik Journal Komunikasi 9 (2). http://ejournal.uinsuka.ac.id/isoshum/profetik/article/view/12 05

Badara, Aris. 2012. Analisis Wacana Teori, Metode, dan Penerapannya pada Wacana Media. Jakarta: Kencana Prenada Media Group.

Bungin, Burhan. 2012. Media dan Politik Menemukan Relasi antara Dimensi Simbiosis-Mutualisme Media dan Politik. Yogyakarta: Graha Ilmu.

Luviana. 2015. "Stereotipe Perempuan Dalam Media." remotivi.or.id, 2015. https://www.remotivi.or.id/amatan/28/stere otipe-perempuan-dalam-media.

Muqoyyidin, Andik Wahyun. 2013. "Wacana Kesetaraan Gender (Pemikiran Islam Kontemporer Tentang Gerakan Feminisme Islam." Jurnal Al-Ulum 13 (2). http://journal.iaingorontalo.ac.id/index .php/au/article/view/198/179.

Permadi, Galih. 2019. "Bambang Driver Taksi Online Perkosa Mahasiswi di Dalam Mobilnya, Korban Lalu Diturunkan di Jalan." TribunJateng.com, Desember 3, 2019.

https://jateng.tribunnews.com/2019/12/03/ bambang-driver-taksi-online-perkosamahasiswi-di-dalam-mobilnya-korbanlalu-diturunkan-di-jalan?page $=1$.

Purbani, Widyastuti. 2009. "Analisis Wacana Kritis Dan Analisis Wacana Feminis." Makalah, Dipaparkan Pada Seminar 
Metode Penelitian Berbasis Gender Di UAD, Yogyakarta 30.

Puspita, Fanny. 2013. "Representasi Stereotipe Perempuan dalam Film Brave." Journal EKomunikasi 1 (2).

http://www.publication.petra.ac.id.

Suyanto.2019. "Sosok Perempuan dalam Pandangan Bung Karno pada Memoar Sarinah: Sebuah Analisis Wacana Kritis Feminis" NUSA: Jurnal Ilmu Bahasa dan Satra 14 (3).

https://ejournal.undip.ac.id/index.php/nusa/ article/view/26961.

Suryorini, Ariana. 2012. "Menelaah Feminisme dalam Islam." Sawwa: Jurnal studi Gender. 7 (2).

http://www.journal.walisongo.ac.id 